\title{
Coastal Zone of Sevastopol on High Resolution Satellite Images
}

\author{
B.A. Dulov ${ }^{1}$, M.V. Yurovskaya ${ }^{1}$, I.E. Kozlov \\ ${ }^{1}$ Marine Hydrophysical Institute, Russian Academy of Sciences, Sevastopol, \\ Russian Federation \\ e-mail: dulov1952@gmail.com \\ ${ }^{2}$ Russian State Hydrometeorological University, Saint-Petersburg, Russian Federation

\begin{abstract}
Landsat-8 data with spatial resolution of 30-100 m provide the ability of regular monitoring of ocean phenomena with scale of $100-1000 \mathrm{~m}$. Sentinel-1 is equipped with C-band synthetic aperture radar. The possibilities of using the high spatial resolution satellite data are considered for observation and monitoring of Crimean coastal zone. Satellite data are analyzed and arranged into a database.

The images allow recognizing the features that affect either the sea surface roughness, or its color characteristics. The observed marine effects are reviewed and the physical mechanisms of their signatures in the satellite images are described. The effects associated with the roughness variability are usually manifested in all Landsat- 8 bands and in Sentinel-1 data, while the subsurface phenomena are visible only in optical data. Confidently observed structures include internal wave trains, filamentous natural slicks, which reflect the eddy coastal dynamics, traces of moving ships and the oil films referred to anthropogenic pollution of marine environment. The temperature fronts in calm conditions occur due to surfactant accumulation in convergence zone. Subsurface processes observed in Landsat-8 images primarily include transport and distribution of suspended matter as a result of floods and sandy beach erosion. The surfactant always concentrates on the sea surface in contaminated areas, so that these events are also observed in Sentinel-1 images. A search of wastewater discharge manifestations is performed.

The investigation provides the basis for further development of approaches to obtain quantitative
\end{abstract} \\ characteristics of the phenomena themselves.
}

Keywords: Landsat-8, Sentinel-1, coastal zone, mesoscale structures, pollution of coastal waters, wastewater.

DOI: 10.22449/1573-160X-2015-6-39-54

(C) 2015, B.A. Dulov, M.V. Yurovskaya, I.E. Kozlov

(C) 2015, Physical Oceanography

\section{Introduction}

In recent years, Landsat satellite data with spatial resolution of $15-100 \mathrm{~m}$, have become freely available. It provided previously unavailable possibility to monitor from the satellite ocean phenomena having the scale of $100-1000 \mathrm{~m}$ regularly. Similar opportunities are opened by means of the data of the radar with Sentinel-1 C-SAR synthetic aperture having $80 \mathrm{~m}$ resolution, which have appeared on open access since October 2014. The aforementioned high spatial resolution satellite data are of demand, primarily for research and monitoring of coastal zones. This is hardly the only list of the important practical applications, which includes mesoscale dynamics of water [1 - 3], monitoring the ecological state of water basins [1, 2, 4], the spread of suspensions [5], the control of pollution of the marine surface by anthropogenic films $[2,6]$, monitoring of the wastewater sources $[2,4$, 7].

For the purpose of the pilot studies of new features of the high-resolution satellite data a database of waters adjacent to the city of Sevastopol has been generated. The database includes all multichannel Landsat-8 (Level 1) images, made within the period from May 2013 to August 2015 and all Sentinel-1 images 
from May to August 2015. This paper presents the results of the analysis of these images. It is aimed to describe information value of the high resolution satellite data for research and monitoring of coastal areas of the Crimea. A review of the phenomena that can be observed with the help of the satellite images and the physical mechanisms of their manifestations as a basis for further development of approaches to obtain quantitative characteristics, are given.

\section{Data and methodology}

Landsat-8 satellite data. Each of the Landsat-8 images covers a rectangular area on the earth's surface of $180 \times 185 \mathrm{~km}$ size. Shooting frequency of the Sevastopol region is 16 days and it is always performed at around 8:30 UTC (11:30 local summer time). All Landsat-8 images (about 20), made in the period from May 2013 to August 2015 in the absence or small number of clouds over the sea, were selected for analysis.

Landsat-8 Level 1 product is a set of images for 11 bands, as well as a file with the image quality assessment included and the text file containing the shooting geometry characteristics and the constants to transfer the code images in spectral brightness or brightness temperature. The following table shows the length of the electromagnetic waves, the spatial resolution of the images and the signal/noise ratio for each channel [8]. Panchromatic channel of the optical range (8th) has a maximum resolution of $15 \mathrm{~m}$, while the resolution of the thermal channels is $100 \mathrm{~m}$. One of the Landsat-8 sensor features is that the signal/noise ratio for them on the order of magnitude is superior the relevant specifications of the Landsat-7 satellite channels.

Landsat-8 channels

\begin{tabular}{c|c|c|c}
\hline Band & Wave length, mkm & $\begin{array}{c}\text { Spatial } \\
\text { resolution, } \mathrm{m}\end{array}$ & $\begin{array}{c}\text { Signal/noise } \\
\text { ratio }\end{array}$ \\
\hline 1 & $0.43-0.45$ & 30 & 238 \\
2 & $0.45-0.51$ & 30 & 364 \\
3 & $0.53-0.59$ & 30 & 302 \\
4 & $0.64-0.67$ & 30 & 227 \\
5 & $0.85-0.88$ & 30 & 204 \\
6 & $1.57-1.65$ & 30 & 265 \\
7 & $2.11-2.29$ & 30 & 334 \\
8 & $0.50-0.68$ & 15 & 149 \\
9 & $1.6-1.38$ & 30 & 165 \\
10 & $10.60-11.19$ & 100 & 238 \\
11 & $11.50-12.51$ & 100 & 364 \\
\hline
\end{tabular}

The following operations were carried out for data analysis:

- the image pixels, where the Level 1 product system formation confidently fixed the presence of clouds or an entry crash occurred (relevant information is included in the quality file) were excluded from consideration;

- transfer to the spectral reflectance, or reflectance temperature (for thermal channels) using a text file was carried out; 
- the clouds and land were excluded (for this we used the 5-th channel corresponding to the closest infrared range, where the brightness of the land and clouds is definitely higher than the brightness of the sea);

- fragments of the images having typical $10-50 \mathrm{~km}$ size, where the contrast of the structures observed was increased by selection of the given brightness range and sometimes by equalization of the histogram, were considered.

Color and continuous-tone figures given below are obtained by two methods brightness chromacoding for one channel (for the sea surface temperature and also in the cases when no histogram equalization have been performed) and $R G B$ format color composite formation from modified signals of the following three channels - the blue ( ${ }^{\text {nd }}$ channel, $B$-matrix), the closest infrared ( $5^{\text {th }}$ channel, $G$ matrix) and the panchromatic one ( $8^{\text {th }}$ channel, $R$-matrix). In the second case, the $2^{\text {nd }}$ and $5^{\text {th }}$ channels were brought to $15 \mathrm{~m}$ resolution applying interpolation. At the same time the color contrasts were obtained, being close to the real ones, but their tints could differ from them because of the brightness transformations preceded. After that the land field was overlaid on the image.

Sentinel-1 satellite data. Sentinel-1 satellite is equipped by the synthesized aperture radar ( $S A R$ ) operating in $C$-range at the electromagnetic length of 5,6 cm. Radar survey repeatability of the research area is $5-7$ days, and in the Sevastopol region it is usually carried out at 04:00 and 16:00 UTC. Radar images used in this process are L1-level data, obtained in Interferometric Wide Swath mode for two polarizations - VV and VH (for vertical transmit and vertical and horizontal receive) with interpolation on the regular grid (GRDH-product) having range and azimuth spatial resolution of $20 \times 22 \mathrm{~m}$ and image size $250 \times 150 \mathrm{~km}$. Within May - August 2015 period 33 Sentinel-1satellite images have been obtained. Image smoothing by adaptive Lee-filter with the running window size $3 \times 3$ or $5 \times 5$ was carried out for the future analysis. See the most informative VV-polarization data discussed below.

Landsat-8 satellite data peculiarities for the Sevastopol region. Two approaches are conventionally applied using optical range satellite images. The first approach is connected with obtaining of the qualitative evaluations of chlorophyll, suspended solid and colored dissolved organic matter concentration $[1,9]$; it requires the atmospheric correction, i.e. the intensity extraction of the part associated with the rising of the water by radiation from each band [10]. This approach is applied out of the sun glint area. The second approach is aimed to allocate the oceanic mesoscale structures connected with variability of sea surface roughness - mean square slope (mss) [11, 12]. It can be applied within the sun glint area, when the brightness of the red and the closest infrared channels is caused mainly by sunlight direct reflection contribution to the signal. At the same time the information extracted from optical satellite images is in many ways similar to the satellite radar data. The possibility of applying of the one or another approach is determined by the latitude, survey local time and season of the year.

Fig. 1 shows an example of the Landsat-8 image of May, 16, 2014. On a color composite we can clearly see the waters of various compositions, localized in Severnaya, Streletskaya, Omega, Kamyshovaya and Kazachyya Bays, and also near Fiolent cape and in the area of the Balaclava Mine Group water runoff. These waters are of different colors and tints and stand out against the surrounding clear water. That is, the quantitative information according to the first conventional approach can be extracted from the Landsat-8 images made near Sevastopol. 
At the same time the left part of the image is embraced by filamentary patterns of the slicks of the natural origin. Such phenomena are observed everywhere in the World Ocean [13], including those in the coastal waters of the Black Sea [6], reflecting the dynamics of the near-surface layer. In Fig 1, a slick hairlines generate a picture in the form of the vortices and umbrella-shaped stream, which in general terms is repeated in Fig. 1, $b$, depicting the surface temperature. Along the pronounced temperature front the band of the almost straight slick is also seen. Slicks as the areas, where the roughness of the sea surface is suppressed, are observed at the radar images $[6,11,13]$ and the satellite ones in the sun glint areas $[11,12]$. Fig. 1, $a$ shows, that the Landsat-8 images in the Sevastopol region reflect the sea surface roughness field, which could be recovered according to a second conventional approach.

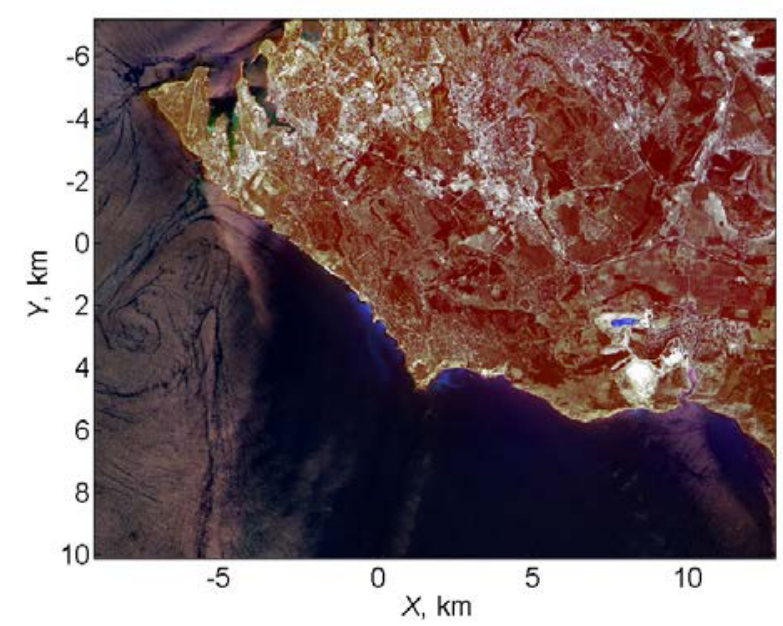

$a$

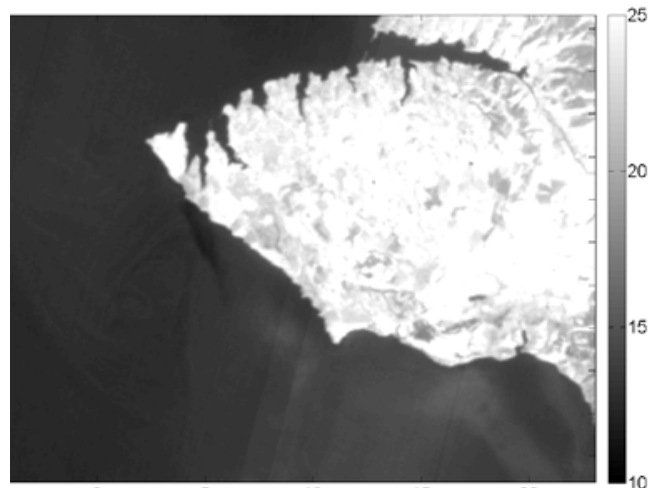

$b$

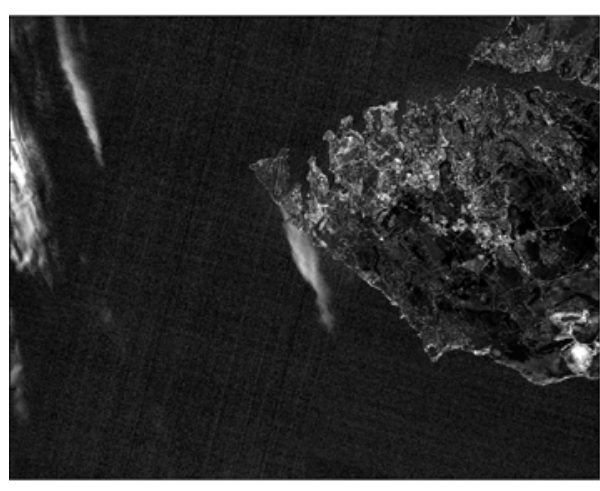

$C$

Fig. 1. Example of the Landsat-8 satellite image (May, 16, 2014): color composite (a), temperature of the sea surface $(b)$, cirrus in the $9^{\text {th }}$ band $(c)$

The review of the examined Landsat-8 images showed that in the Sevastopol region there is always an interim mode when the contribution of direct sunlight reflection from the sea surface is the essential, but non- dominant component of the brightness of the optical channels. Thus, conventional approaches to the use of images, strictly speaking, are not applicable. Nevertheless, the images contain 42

PHYSICAL OCEANOGRAPHY NO. 6 (2015) 
plenty of the information that can be used at the qualitative level. This is demonstrated in the following sections of this issue.

The Landsat-8 data also contain the special channel $\left(9^{\text {th }}\right)$, intended for registration of cirrus. These clouds are almost transparent in all the other bands, but can significantly distort the observed features in the images. In Fig. 1, $a$ to the south of Chersonesus Cape the "pink" region is picked out. It stands adjacent to the coast and repeats in general in the temperature field in Fig. 1, b. Fig. 1, $c$ shows a fragment of the same image (covering a larger area), but for the $9^{\text {th }}$ channel. Cirrus is clearly distinguished. As follows from the figures, the discussed feature is a manifestation of cirrus in the visible and close infrared channels. When analyzing the images we controlled the correctness of the conclusions, taking also into account the data of the 9th channel.

\section{Structures in the field of the sea surface roughness}

The work [12] deals with interpretation of the optical images obtained from MODIS/Terra and MODIS/Aqua satellites in the area of sun glint for the Black Sea water area in the spring-summer period of 2013. Spatial distribution of the aforementioned data is $250 \mathrm{~m}$. The fields of the sea surface roughness characteristics - the dispersion of its slopes mss (mean square slope) were calculated applying the methodology [11]. In the fields of roughness a number of the following mesoscale phenomena was selected and discussed: internal waves, vortex-type structures, fronts and features of the coastal dynamics, anthropogenic slicks and traces of the moving vessels. Applying the Landsat-8 data with $30 \mathrm{~m}$ spatial resolution in the present work, we found an abundance of similar structures that exist in the roughness of the sea surface.

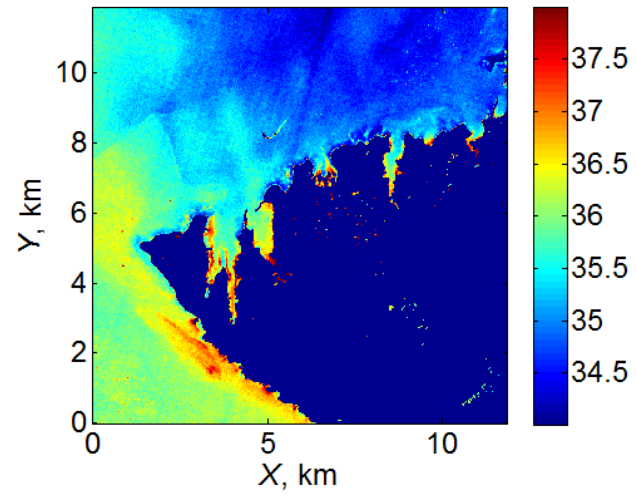

a

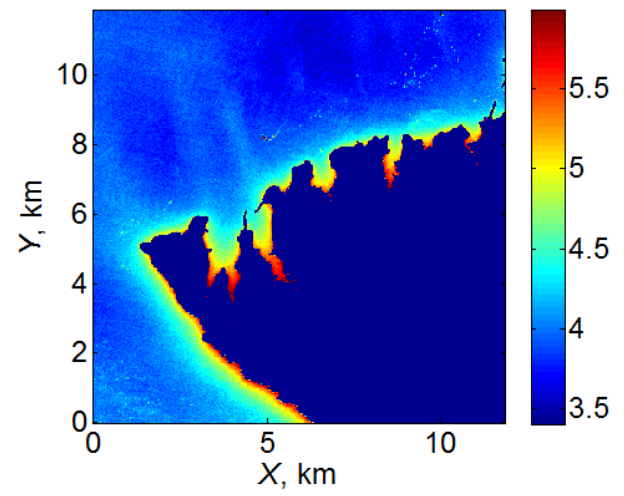

$b$

Fig. 2. Fragment of the Landsat-8 satellite image (November, 8, 2014): spectral radiance in the bands $2(a)$ and $5(b)$

In this work Figure 2 illustrates the approach used to separate the roughness effects and color of the waters. The structures tied with the roughness variability are simultaneously observed in all the channels from the $1^{\text {st }}$ to $8^{\text {th }}$, while the structures associated with the rising of the water column radiation, are found only in the optical bands $1-4$ and 8 and are absent in infrared and near- infrared bands. Fig. 2 shows the fragment of the image in the $2^{\text {nd }}$ (blue) and $5^{\text {th }}$ (near infrared) bands. High brightness extended areas for the both bands, coming from Kazachyya Bay, are selected (as well as from other bays, but less contrast ones). These features should be 
attributed to the effects of the sea surface roughness. At the same time, in the blue channel the contrast feature having the shape of an elongated bright spot, oriented along the coastline to the south of Chersonesus Cape, is observed (Fig. 2, a). This peculiarity is found in all the optical channels, but is absent in in the channels $5-7$ (Fig. 2, b). Therefore, it should be attributed to the subsurface phenomena.

Increase of the mss surface can cause both the increase and decrease of the image brightness in the solar glint area [11, 12]. In the given Landsat-8 images we can confidently identify the slicks - roughness suppression fields (lower mss values) under the influence of surface active substances (SAS). The slicks in all the images have a negative contrast (Fig. 1, a). We shall therefore assume that the brightness increase in the structure associated with the variability of roughness corresponds to an increase of mss.

A number of the articles describe the wind jets observed on radar images of the Black Sea $[14,15]$. Such jets are formed due to wind jet flow around the coastal orographic features and extend for tens of kilometers from the coast, leading to an increase of $m s s$ in the underlying water surface. Fig. 2 probably shows a similar phenomenon, but at smaller spatial scales. Air flows with high speed can be formed in the gullies (ravines), adjacent to the bay, as the slope wind. Their manifestation in the form of the increased brightness bands outgoing from bays over distances up to several kilometers from the coast can be seen in Fig. 2. This phenomenon has not been adequately studied, and satellite data with high spatial resolution provides new opportunities for its research.

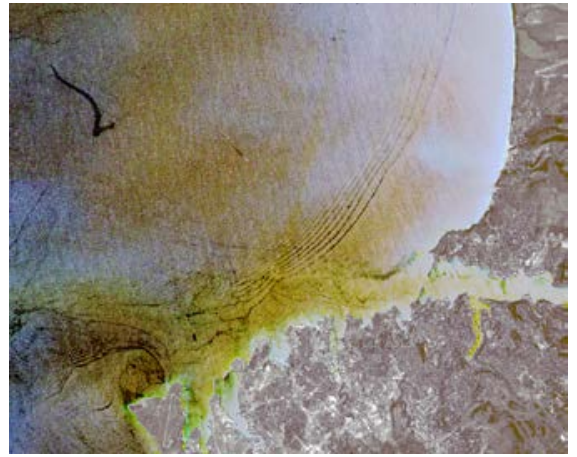

$a$

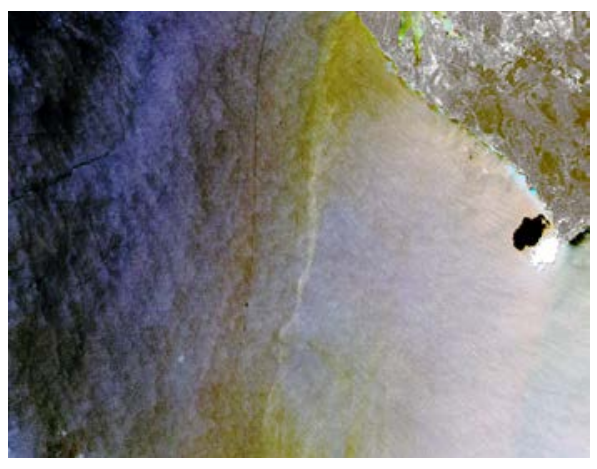

C

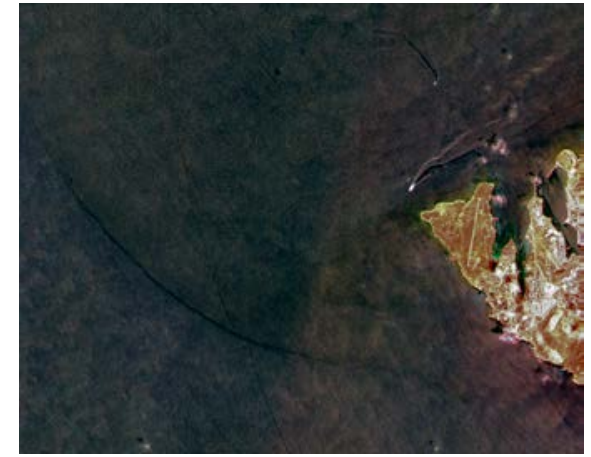

b

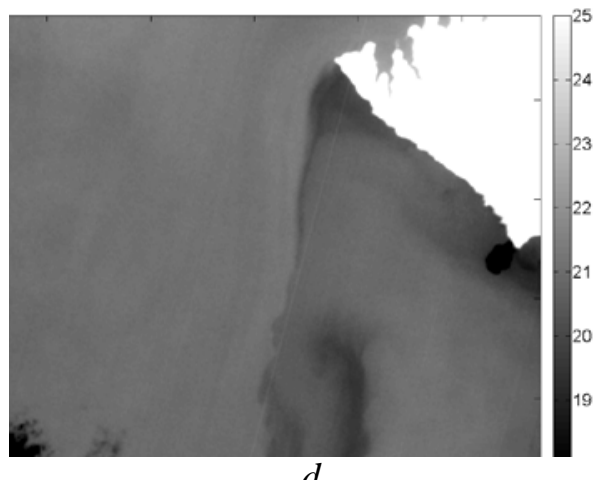

$d$

Fig. 3. Fragments of the Landsat-8 satellite image: color composites of August, 1, 2013 (a), July, 6, 2015 (b), July, 16, 2013 (c) and temperature of the sea surface in July, 16, 2013 (d) 
Fig. 3 shows examples of the various structures in the roughness field, which are observed in the Landsat-8 data. Figure 3, a clearly distinguishes the internal wave packets, filamentary natural slicks stirring in the shape of the vortex near Chersonesus Cape, anthropogenic slick in the upper left corner of the image. In Fig. 3, b, you can see the traces of moving vessels and film anthropogenic pollutions having characteristic shape and being the consequence of the unauthorized fuel discharge from the vessels to the sea [6].

Natural slicks appear due to SAS formation as a result of vital functions of the microorganisms. Besides the films of SAS concentrate along the convergence areas in the subsurface layer, and the picture formed at the image is found to be the consequence of the water dynamics $[6,13]$. Alternating areas of the convergence and divergence are being visible in the optical range during distribution of the internal waves owing to natural SAS accumulation in the convergence areas. Convergence of the surficial current can be expected under inleakage of one water mass onto another, so the SAS films can accumulate along the mesoscale fronts. The aforementioned Fig. $1, a, b$ shows this very effect when the surface temperature front is visible in the optical range due to the slick elongated along it. However, increasing the wind speed up to $4-7 \mathrm{~m} / \mathrm{s}$, the wavebreaking appears, and destroys the surficial films. Besides in the convergence areas due to the hydrodynamic reasons (see, e. g. [16]) the short-wave spectral density and the intensity of wavebreaking increase. As a result, the convergence area, being the field of the sea surface roughness increase, should be manifested in the analyzed data in a form of the high-brightness area. Fig. 3, $c$ shows the example of the data permitting such interpretation. Fig. $3, d$ demonstrates the corresponding temperature field, characterized by the distinct front. As we can see from Fig. 3, c, there is a bright band elongated along the front. This band is visible in the channels $1-8$ and can be interpreted as the increase of the surface roughness in the convergence area.

There is a wide variety of the studies on the problem of the distinction of anthropogenic and natural slicks and also the one of the identification of local reduction of the brightness of the optical and radar images, looking like slicks, (see [6] for the review). Anthropogenic slicks connected with the fuel discharge, unlike the filamentary natural SAS, are characterized by the distinguished boundary and increased contrast. The slicks seen in the upper left corner in Fig. 3, $a$ and diagonally in Fig 3, b, are referred to the anthropogenic ones according to such criteria. The connection of the slick with the vessel created it, is often quite visible, as in Fig. 3, $b$, to the north of Chersonesus Cape. At the same time the vessels look like bright dots, which when moving generate the characteristic trace resembling the bright "moustaches", tied with the vessel waves (vessel traces can also be seen in Fig. 5, $a$ below). In Fig. 3, $b$ the anthropogenic slick pulls behind the vessel in space between the "moustaches". The slick elongated diagonally the image seems to mark the trajectory of the vessel passed.

The structures described in the field of the sea surface roughness are naturally observed also in the radar images of the considered water area. For example, Fig. 4 shows the fragment of the Sentinel-1 satellite, where you can clearly see the elongated bands of the slicks. This Figure also demonstrates the contamination of the Sevastopol bays by the surficial films. 


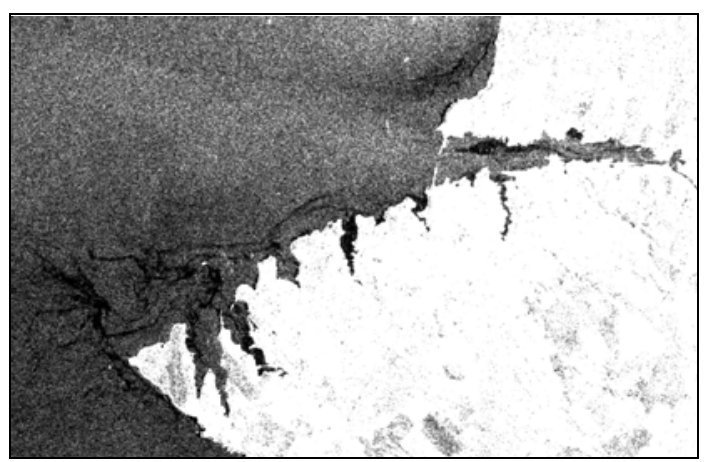

Fig. 4. Fragment of the radar image of the Sentinel-1 satellite of July, 13, 2015 (03:56 UTC)

\section{Freshets and distribution of the suspension}

The suspended matter at the expense of radiation dispersion leads to brightness increase in the images in the optical channels, especially in the red one, and under the high concentrations in the layer in directly close to the surface - in the nearest infrared range [17]. Consideration of the suspensions as the tracers in the moving water masses permits to analyze the dynamics of the waters in the costal zones [1, 2]. In the work [5] on the grounds of the analysis of the Landsat-series satellites the suspension distribution patterns near the western coast of the Crimea, including their relationship with the wind direction, were found. To the north of Sevastopol Bay the sources of the suspension in the sea water are freshets, undercutting of the sand beaches and, probably, the suspended matter transfer by the streams from the North from Gulf of Kalamita. In the Landsat-8 images in the optical and the near- infrared channels in this region, the coastal strip, as a rule, is brighter than the seaward area.

In May - June 2015 there was a high level of the precipitation in the Sevastopol region. The continuous rains caused the anomalous freshets of the Kacha and the Belbek Rivers. It resulted in flood of the fields, inrush of the fishery pond, washing away of the road and destruction of the shore part. The front between the waters of the yellow and blue colors was clearly seen. These consequences were fixed by the experts, who had visited areas of the local disasters (personal message of Yu.N. Goryachkin dated 2015). Fig. 5, $a, b$ show the images dated June, 4 and July, 6, 2015, corresponding to the moments of the disastrous suspension discharges to the sea. They demonstrate plumes, coming from estuaries of the Kacha and Belbek rivers, and distribution of the pollutions in the costal zone. Fig. 5, $c$ shows the sea surface temperature corresponding to Fig. 5, $a$. Temperature in the estuaries of the rivers is lower than in the surrounding sea area. In the Fig. 5, $a, c$ you can see the pollutions to distribute in the sea at the $10 \mathrm{~km}$ distance and more due to the coastal eddy dynamics of the waters.

A number of the examples of the suspension distribution at the large distance is described in the work [5]. The additional details of these phenomena are shown in Fig. 5, $d-f$. The image in Fig. 5, $d$ can be interpreted as the separation of the area of pollutions having the longitudinal size about $3-4 \mathrm{~km}$ of the bulk of the roiled waters. Fig. 5, $e$ shows the way of the pollutions distribute along the Sevastopol coastal line and rush in the high seas near Chersonesus Cape in the form of the spots having typical size of several kilometers. As a rule, such patterns are partly explained by the water dynamics revealed in the surficial temperature. Fig. 5, $f$ displays the temperature field corresponding to Fig. 5, $e$, which could be interpreted as the mesoscale turbulence development at the border of the separation 
of the water masses of different temperatures. Then the capture of the polluted water fractionally in the form of the spots observed can be connected with the random nature of this process.

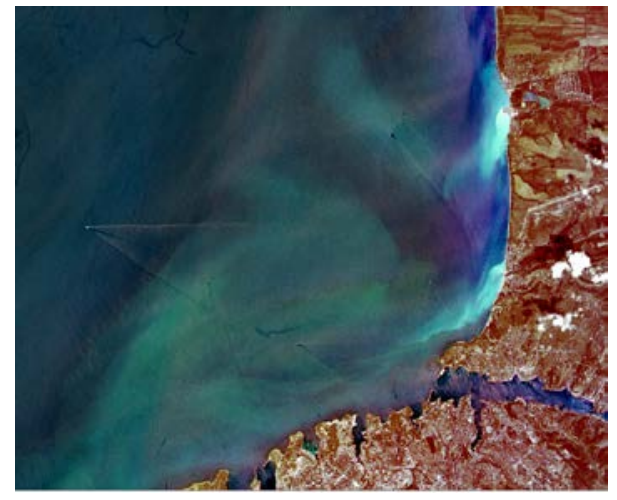

$a$

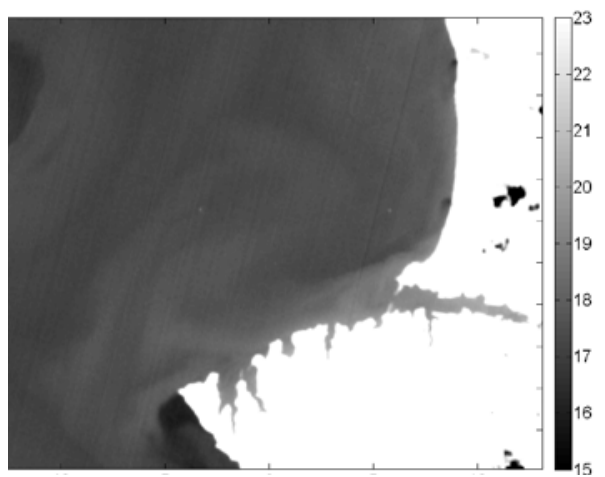

C

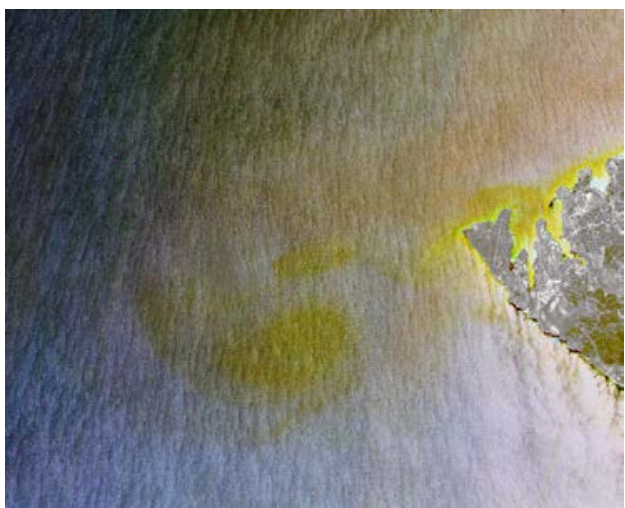

e

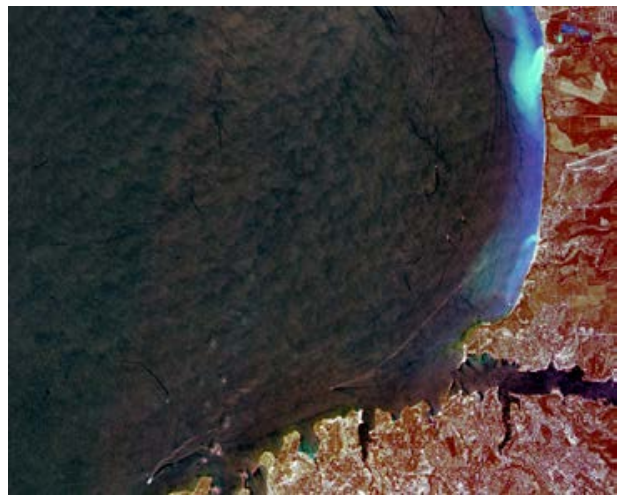

$b$

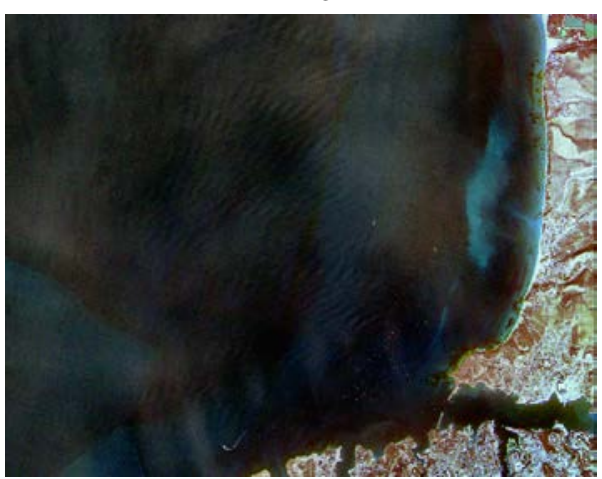

$d$

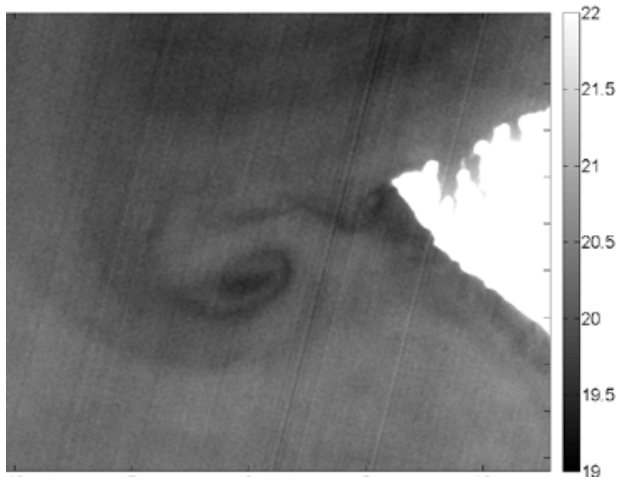

$f$

Fig. 5. Freshets and suspension distribution in the area to the north of Sevastopol: the freshets of June, $4(a)$ and July, $6(b)$, 2015; the distribution of roiled waters on November, $8(d)$ and July, $19(e), 2014$. Sea surficial temperature of June, 4, 2015 (c) and July, 19, 2014 (f) 


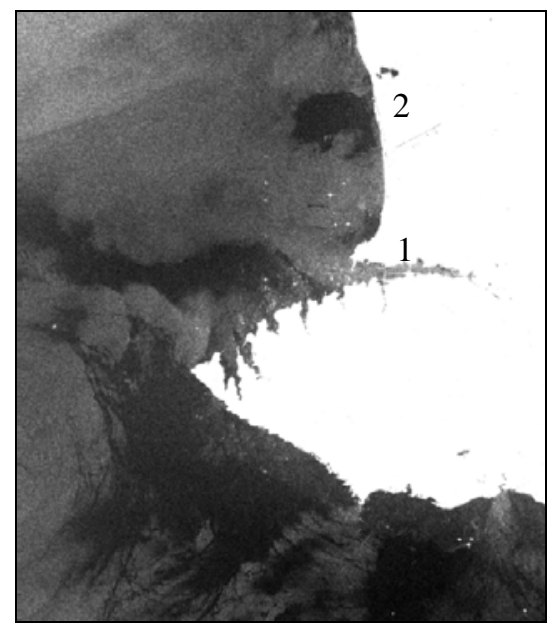

$a$

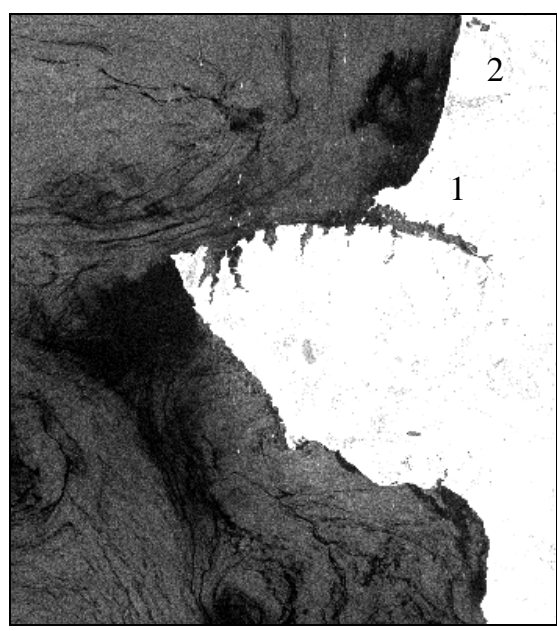

$b$

Fig. 6. Fragments of the Sentinel-1 satellite radar image including the examples of the monitoring of the radar signal low dispersion in the area of the intense river runoff on May, $21(a)$ and July, $9(b)$, 2015

During the flow of the waters the surface-active substances get from the land to the sea that should lead to the gravity-capillary ripple suppression and, consequently, to the radar signal suppression. Images from the Sentinel-1 satellite during the period of the 2015 freshets shown in Fig. 6 really demonstrate the negative radar contrasts in the area captured by the roiled waters. It is necessary to note that the radar images show first and foremost the variability of the wind velocity field, which is reflected in the spectral density of the short wind waves. The effects of the wind velocity and SAS impact are inseparable under the "brightness" of one channel of the radar image. But, taking into consideration the sizes and location of the dark spots in Fig.6 and supposing that borders of the SAS slicks look finer than the ones of the local wind weakening, we can come to the conclusion that the peculiarities marked by the numbers in the Figure relate to the water runoffs from the Belbel (1) and Kacha (2) rivers. In Fig. 6, $a$ (May, 21, 2015) you can find out the region of about $14 \mathrm{~km}^{2}$, situated in the area of the roiled water distribution as a result of the freshet at the Kacha River. The region of the same size and in the same area can be also seen in Fig. 6, b (July, 9, 2015). Here you can see the filamentary slicks related with the natural origin SAS, having already been discussed analyzing Fig. 4. These slicks can be observed during low wind velocities (less than $4-7 \mathrm{~m} / \mathrm{s}$ ), when there is no destruction of the films as a result of the breakdown of the wind waves. The fact that they are not observed in the upper part of Fig.4, but appear in its lower part justifies the higher wind velocity in the area to the north of Sevastopol Bay. It is the indirect confirmation that the dark spots 1 and 2 are not related with the local weakening of the wind.

\section{Problem of the wastewater distance monitoring}

Control of the environmental pollution by the city and industrial wastewater applying the satellite technologies is the actual problem nowadays. The problem review is given in the works $[2,4,7,18]$. The main discharge of the city 
wastewater is realized through the pipeline. One of its parts about $3.3 \mathrm{~km}$ length lies at the $50 \mathrm{~m}$ bottom to the south of Chersonesus Cape [19]. The diffuser is situated on the depth over $50 \mathrm{~m}$ to prevent the wastewater ascent to the nearsurficial layer. However the ascent is essentially possible under the definite hydrological conditions [4, 7]. In this case the wastewater mass ("torch", "plume") can be monitored by the aerospace methods, if it is different from the surrounding water by its optical features. Monitoring of the main discharge of the Sevastopol wastewater by the optical scanner from the Resurs satellite is described in the work [18], data about the discharge at the Hawaiian Islands are given in the works [4, $18]$ and in Gelendzhik - in [2, 20]. The SAS ascent from the wastewater to the sea surface should lead the formation of the vast slick. Monitoring of the supposedly aforementioned phenomenon near the main wastewater discharge of Sevastopol near Chersonesus Cape had already been mentioned in the work [7], where the Almaz satellite radar image was analyzed. Interaction of the buried wastewater jet with the density gradient in pycnocline can cause the internal waves [7, 21]. The observation of such waves can be useful for the wastewater discharge diagnosis [4]. These results motivated the search of the wastewater manifestations in the Landsat- 8 and Sentinel-1 data in the framework of the present research.

Fig. 7, $a$ show the fragment of the Landsat-8 satellite image of November, 8, 2014, which supposedly contains the wastewater plume. The plume length is about $3 \mathrm{~km}$, the width - about $600 \mathrm{~m}$. The plume image is primarily related with the radiation coming out of the water, as it is found in all the optical channels, but is absent in the close infrared range (see Fig. 2, including the plume image discussed). The similar plumes in the same place were also identified on the images of November, 5, 2013, January, 8, 2014 and May, 19, 2015. The first two images were sufficiently less contrast (Fig. 7, b), on May, 19, 2015 the plume length reached $4 \mathrm{~km}$ and it was situated on the same distance from the coast, but was shifted to the south-east (Fig. 7, $c$ ). In Fig. 7 the pipeline entrance point into the sea (arrow) and approximate diffuser position (star) are marked. All the plumes found were situated sufficiently closer to the coast than their supposed source - the sewer diffuser. This circumstance gives birth to the supposition the observed plumes are related to some other source. Fig. $7, d$ shows fragment of the Landsat-8 satellite image dated July, 3, 2014, where there is no plume, but we can definitely see the slicks coming from the coast in the point situated about $1 \mathrm{~km}$ to the north from the pipeline entrance point into the sea. In the same point (Fig. 7, $a-c$ ) we can find out the runoff of the waters with the increased turbidity. Probably, this very runoff caused the formation of the plumes discussed.

There are also city sewers to the north of Sevastopol Bay; however it is difficult to focus their manifestations according to the Landsat-8 data against the background of the river runoffs undercutting of the sand beaches. Nevertheless after the anomalous runoffs related to the 2015 freshets had stopped, the Sentinel-1 data continuously contained the areas of the lowered brightness, coming from the points where the main sewers of the Sevastopol Northern Side were situated. Fig. 8 shows fragments of the radar images where positions of the sewers are marked by arrows (see also Fig. 4, where you can find the lowered brightness area coming from the coastal point marked by the lower arrow in Fig. 8). 


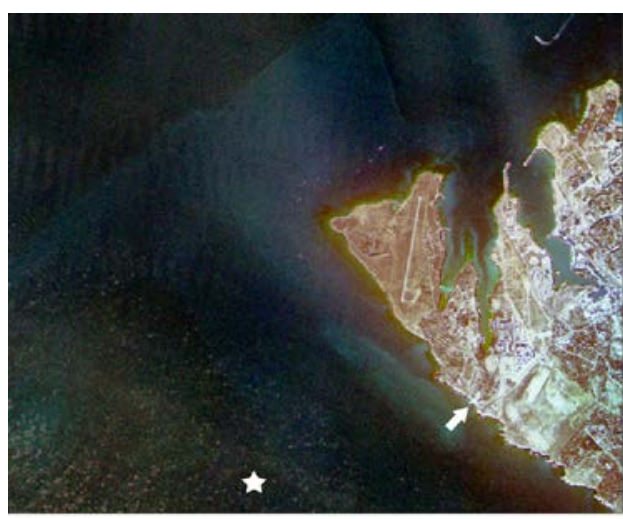

$a$

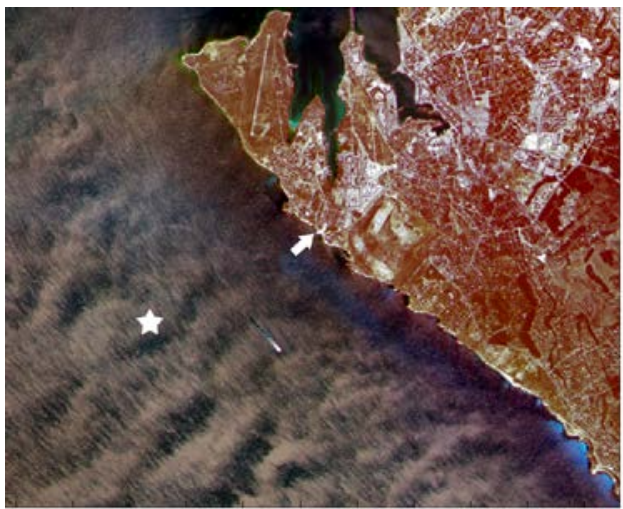

$C$

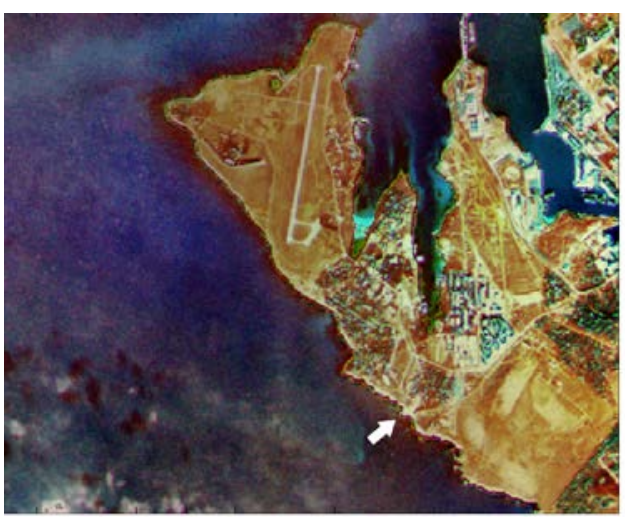

$b$

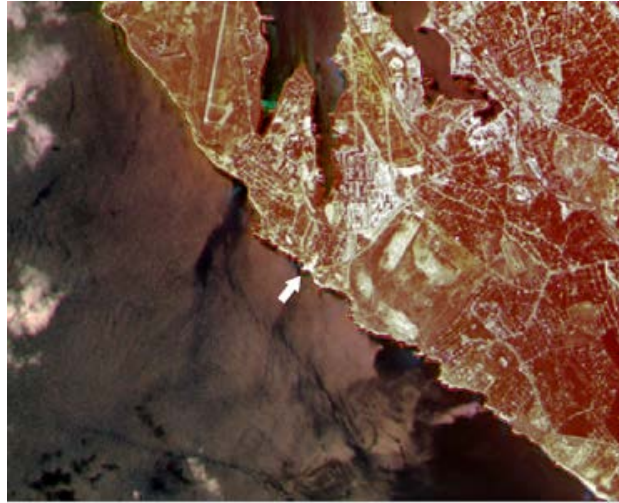

$d$

Fig. 7. Fragments of the Landsat-8 satellite images with the possible signs of the city sewer. Color composites dated November, 5, 2013 (a), January, 8, 2014 (b), May, 19, 2015 (c) and July, 3, 2014 (d). Approximate diffuser position is marked by star and the pipeline entrance point into the sea - by arrow

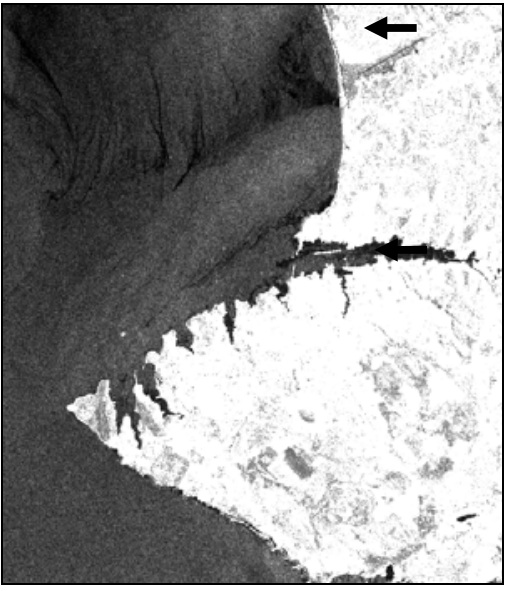

$a$

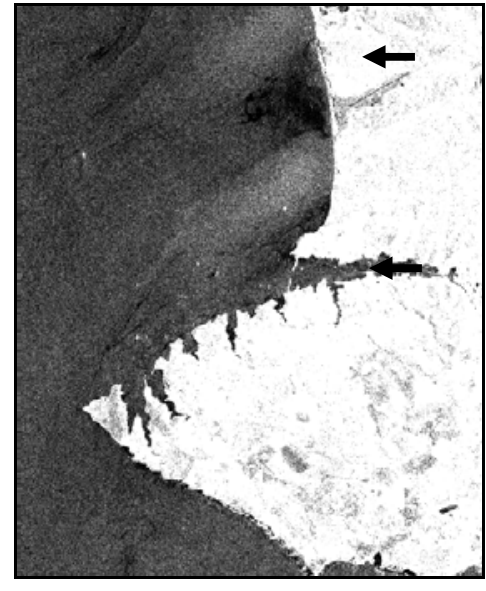

$b$

Fig. 8. Fragments of the Sentinel-1 satellite radar images containing the examples of the monitoring of radar signal low dispersion areas in the places of the expected wastewater discharge on July, 25 (a) and August, 18 (b), 2015. The arrows mark the location of the city sewer 


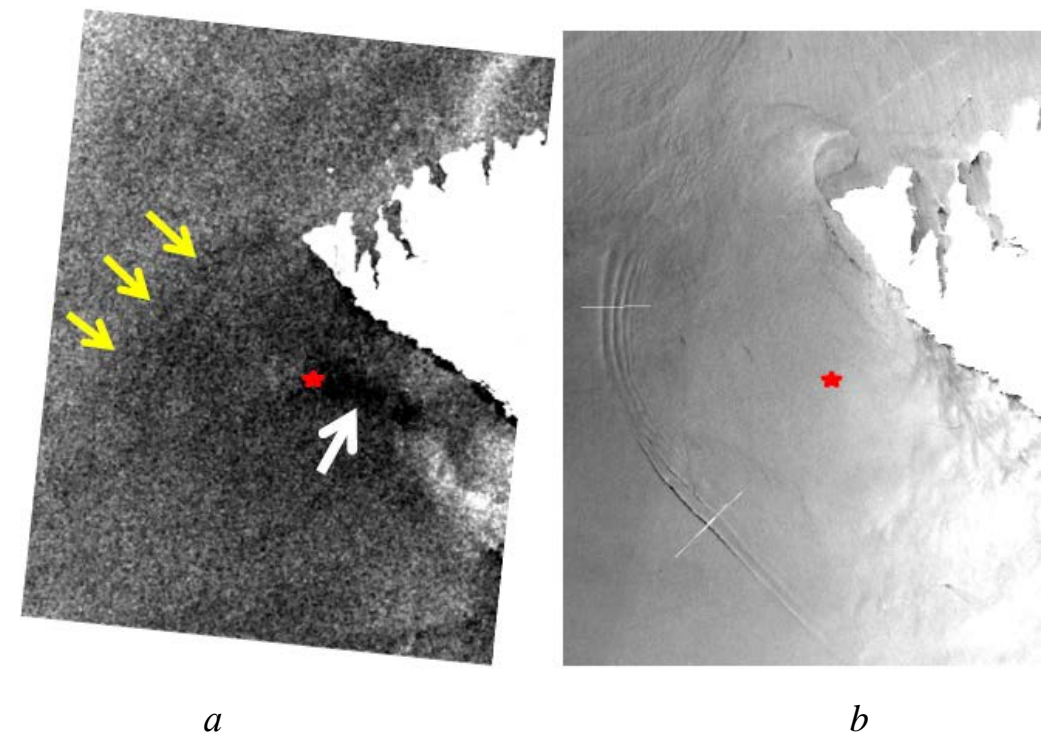

Fig. 9. Example of the anomaly monitoring in the sea surface in the area of the Sevastopol deep sea sewer in the Sentinel-1satellite radar image dated August, 6, 2015 (a) and in the Landsat-8 satellite optical image (close infrared channel) dated June, 22, 2015 (b)

\section{Conclusion}

Thus, the high spatial resolution data obtained from the Landsat-8 and Sentinel-1 satellites, give a wide range of possibilities for research and monitoring of the coastal areas. Multi-channel images of Landsat-8 permit to observe the peculiarities of the sea environment affecting either the sea surface roughness or its color features. During the analysis both types of the phenomena can be divided into the following ones: the effects related to the roughness change, seen, as a rule, in all the channels, and near-surface effects, detected only in the optical bands. To the clearly observed structures, affecting the roughness, we can refer trains of the internal waves, natural filamentary slicks, reflecting the coastal dynamics in the form of the eddies and fronts, traces of the moving vessels, areas of anthropogenic film contamination having the specific appearance, accompanying the illegal oil discharge to the sea. Temperature fronts under the calm conditions reveal only due to the SAS accumulation in the convergence area and formation of the slick, prolated along the front and observed in the form of the dark filament. Under the wind conditions the temperature front can also be observed in the form of the bright filament, due to the intensification of the roughness and wavebreaking in the convergence zone. Local orographic peculiarities can cause the wind currents with typical scale of several kilometers reflected in the field of roughness and observed in the form of the high brightness bands. The indicated features of the field of roughness can be also monitored in the Sentinel-1 radar data.

Subsurface processes observed in the Landsat- 8 satellite optical band include, first of all, the transfer and distribution of the suspension due to the freshets and undercutting of the sand beaches. At the same time in the polluted areas on the sea surface the SAS concentrate, owing to that the aforementioned areas are also PHYSICAL OCEANOGRAPHY NO. 6 (2015) 
observed in the Sentinel-1 satellite radar images. Particular attention in the present study is paid to the search of the manifestations of the main wastewater discharge of Sevastopol in the satellite data. There were detected possible manifestations in the form of plume, which is different from the surrounding waters under the optical features and has the longitudinal size $2-4 \mathrm{~km}$ and the diametrical one - about $0.5 \mathrm{~km}$. This formation was observed between the main discharge diffuser and coastal line, besides it was substantially closer to the coast than to the diffuser. However, we are not confident in the fact that the discovered feature is the result of the wastewater discharge through the buried diffuser, but not the manifestation of the unknown pollution source. It should be underlined that in the Landsat-8 data we observe the distribution of the SAS and waters having the anomalous optical features from the same point situated a kilometer to the north.

The following observations testify in the favor of the existence of the wastewater floating jet manifestations in the satellite data. In the Sentinel-1 satellite radar image the less rough surface area with the typical size of several kilometers situated above the diffuser was detected. This smoothing of the surface above the floating jet can be explained by the ascent of SAS separated from the buried wastewater. At the same time the internal waves were distributed from the area of smoothing. This is the way it should occur during the interaction of the floating jet and pycnocline in accordance with the mathematical and laboratory simulation [7, 21]. Distribution of the internal waves from the area of the diffuser was also detected in the Landsat-8 data of the other date.

The authors express deep gratitude to Professor V.N. Kudryavtsev (RSHU, St. Petersburg; MHI, Sevastopol) for discussion of the work and precious ideas and also to Yu. N. Goryachkin (MHI, Sevatopol) for supplying useful information on the considered phenomena.

Acknowledgements. The research was carried out in Marine Hydrophysical Institute RAS under the sponsorship of the Ministry of Education and Sciences of the Russian Federation within the framework of the FTsP "Research and Development in Priority Development Directions of the scientific-technological complex in the Russian Federation 2014 - 2020" (unique project code RFMEFI57714X0110) and RFBR (scientific project No.15-35-50726 "Satellite Multipolar RSA Measurements in the Black Sea Coastal Waters near the Crimea: Pilot Research”).

\section{REFERENCES}

1. Robinson, I.S., 2010, "Discovering the Ocean from Space. The unique applications of satellite oceanography”, Series: Springer Praxis Books, Subseries: Geophysical Sciences, UK, Springer and Praxis Publishing, 638 p. 
2. Lavrova, O.Yu., Kostyanoi, A.G., Lebedev, S.A. [et al.], 2011, “Kompleksnyy sputnikovyy monitoring morey Rossii [Complex satellite monitoring of the seas of the Russian Federation]”, Moscow, IKI RAN, 480 p. (in Russian).

3. Stanichniy, S.V., Solov'yov, D.M., Kubryakov, A.A. [et al.], 2014, "Harakteristiki poverkhnostnogo sloya morya v rayone Yuzhnogo berega Kryma po sputnikovym dannym mezhgodovaya i sezonnaya izmenchivost' [Surficial layer features of the sea in the region of the South Coast of the Crimea according to the satellite data - interannual and seasonal variability]", Monitoring Pribrezhnoy Zony na Chernomorskom Eksperimental'nom Podsputnikovom Poligone, edited by Ivanov V.A, Dulov V.A., Sevastopol, ECOSIGidrofizika, pp. 335-372 (in Russian).

4. Bondur, V.G., 2011, "Satellite monitoring and mathematical modeling of deep runoff turbulent jets in coastal water areas”, Waste Water - Evaluation and Management, Croatia, InTech, pp. 155-180.

5. Aleskerova, A.A., Kubryakov, A.A., Stanichniy, S.V., 2015, "Rasprostranenie vzveshennogo veshchestva pod vliyaniem shtormovykh vetrov u zapadnogo poberezh'ya Kryma po opticheskim dannym vysokogo razresheni [Suspension distribution under the influence of the storm winds near the western coast of the Crimea according to the high resolution optical data]”, Sovremennye Problemy Distantsionnogo Zondirovaniya Zemli iz Kosmosa, vol. 12, no. 1, pp. 63-71 (in Russian).

6. Malinovsky, V.V., Ivanov, V.A., Sandven, S., Dulov, V.A. 2006, "Nablyudeniya zagryazneniy poverkhnosti morya po radiolokatsionnym dannym [Sea surface pollution observation with the use of radar data]", Ekologicheskaya bezopasnost' pribrezhnoy $i$ shel'fovoy zon i kompleksnoe ispol'zovanie resursov shel'fa, no. 13, pp. 99-110 (in Russian).

7. Bondur, V.G., Gerebenyuk, Yu.V., 2001, "Distantsionnaya indikatsiya antropogennykh vozdeystviy na morskuyu sredu, vyzvannykh zaglublennymi stokami: modelirovanie, eksperimenty [Remote indication of the anthropogenic impacts on the sea environment caused by buried wastewater discharge: simulation, experiments]”, Issledovanie Zemli iz Kosmosa, no. 6, pp. 49-67 (in Russian).

8. Landsat-8 (L8) Data Users Handbook, LSDS-1574 Version 1.0, Department of the Interior U.S. Geological Survey, June 2015, 105 p., http://landsat.usgs.gov/landsat8.php.

9. Robinson, I.S., 2004, "Measuring the Oceans from Space. The principles and methods of satellite oceanography”, Series: Springer Praxis Books, Subseries: Geophysical Sciences, UK, Springer and Praxis Publishing, 669 p.

10. Gordon, H.R., Wang, M., 1994, "Retrieval of water-leaving radiance and aerosol optical thickness over the oceans with SeaWiFS: a preliminary algorithm,”Appl. Opt., vol. 33, no. 3, pp. 443-452.

11. Kudryavtsev, V., Myasoedov, A., Chapron, B. [et al.], 2012, "Joint sun-glitter and radar imagery of surface slicks”, Rem. Sens. Environ., vol. 120, pp. 123-132.

12. Yurovskaya, M.V., Kudryavtsev, V.N., Chapron, B., Dulov, V.A., 2014, “Interpretatsiya opticheskikh sputnikovykh izobrazheniy Chernogo morya $v$ zone solnechnogo blika [Interpretation of the optical satellite images of the Black Sea in the area of the sun glint]", Morskoy gidrofizicheskiy zhurnal, no. 4, pp. 68-82 (in Russian).

13. Beal, R., Kudryavtsev, V., Thompson, D., Grodsky, S. [et al.], 1994, "Large and small scale circulation signatures of the ERS-1 SAR over the Gulf Stream", Proc. Second ERS-1 Symposium (11-14 Oct. 1993), Hamburg (Germany), ESA, pp. 340-346.

14. Malinovskiy, V.V., Pustovoitenko, V.V., Kudryavtsev, V.N., 1998, “Ispol'zovanie informatsii RLSBO ISZ “Sich-1" dlya nablyudeniya Chernogo i Azovskogo morey [Application of the AES Sich-1 information for the Black and Azov Sea monitoring]”, Sistemy kontrolya okruzhayushchey sredy, pp. 162-173 (in Russian)

15. Ivanov, A.Yu., Antonyuk, A.Yu., 2013, “Anomal'no sil'nye bory v Chernom more po dannym sputnikovykh nablyudeniy [Anomalously strong boras in the Black Sea under the satellite monitoring data]”, Issledovanie Zemli iz Kosmosa, no.1, pp. 32-43 (in Russian). 
16. Dulov, V.A., Zapevalov, A.S., Bolshakov, A.N. [et al.], 1999, "Proyavlenie dinamiki vody v pribrezhnoy zone $v$ pole obrusheniy vetrovykh voln [Manifestation of the water dynamics in the coastal zone in the wreckage of the wind waves]", Morskoy gidrofizicheskiy zhurnal, no. 4, pp. 3-17 (in Russian)

17. Wang, J., Lu, X., Liew, S. [et al.], 2009, "Retrieval of suspended sediment concentrations in large turbid rivers using Landsat ETM+: an example from the Yangtze River, China”, Earth Surf. Process. Landform, vol. 34, pp. 1082-1092.

18. Bondur, V.G., 2004, "Aerokosmicheskie metody v sovremennoy okeanologii [Aerospace methods in the modern oceanography]", Novye Idei $v$ Okeanologii, edited by M.E. Vinogradov, S.S. Lappo, M., Nauka, pp. 55-117 (in Russian).

19. Dolotov, V.V., Konovalov, S.K., Romanov, A.S. [et al.], 2012, “Biogeokhimicheskiy potentsial kak osnova dlya rayonirovaniya morskoy sredy Sevastopol'skoy bukhty [Biochemical potential as the basis for sea environment regionalization of Sevastopol Bay]”, Morskie Resursy Pribrezhnoy Zony Ukrainy, pp. 206-221 (in Russian).

20. Bondur, V.G., Vorob’yov, V.E., Grebenyuk, Yu.V. [et al.], 2012, “Issledovaniya poley techeniy i zagryazneniy pribrezhnykh vod na gelendzhikskom shel'fe Chernogo morya s ispol'zovaniem kosmicheskikh dannykh [Research of the fields of currents and pollution of the coastal waters at the Gelensdzhik shelf of the Black Sea applying space data]”, Issledovanie Zemli iz Kosmosa, no. 4, pp. 3-11 (in Russian).

21. Bondur, V.G., Ezhova, E.V., Grebenyuk, Yu.V. [et al.], 2010, "Poverkhnostnye proyavleniya vnutrennikh voln, izluchaemykh zaglublennoy plavuchey struey. Ch. 3. Poverkhnostnye proyavleniya vnutrennikh voln [Surficial manifestations of the internal waves, studied by the buried floating jet. Part 3. Surficial manifestations of the internal waves]”, Izv. RAN. Fizika Atmosfery i Okeana, vol. 46, no. 4, pp. 1-10 (in Russian) 